\title{
パッシブサンプラーを用いる山間部における大気中二酸化 窒素及び二酸化硫黄の簡易測定法
}

\author{
山田 悦 ${ }^{\text {B* }}$, 吉田 大作 ${ }^{*}$, 胡 連春**, 山田 武***
}

A simple measurement method of atmospheric nitrogen dioxide and sulfur dioxide in mountains using passive samplers

\author{
Etsu Yamada, Daisaku Yoshida ${ }^{*}$, Lian-Chun $\mathrm{Hu}^{* *}$ and Takeshi YamadA ${ }^{* * *}$ \\ *Department of Chemistry and Materials Technology, ${ }^{* *}$ Center for Environmental Science, \\ *** Department of Polymer Science, Kyoto Institute of Technology, Sakyo-ku, Kyoto 606
}

(Received 26 July 1996, Accepted 23 August 1996)

\begin{abstract}
Passive samplers for the determination of $\mathrm{NO}_{2}$ and $\mathrm{SO}_{2}$ in the ambient air of mountains were investigated and applied to a spatial analysis of air pollutants along the slope of Mt. Hiei. Yanagisawa-type samplers were used for determining the atmospheric $\mathrm{NO}_{2}$. After they were exposed for $24 \mathrm{~h}$, the absorbed $\mathrm{NO}_{2}$ was measured colorimetrically by the Saltzman method. However, $\mathrm{SO}_{2}$ samplers comprising an absorbent filter containing sodium carbonate solution were made and exposed for 20 days. The absorbed $\mathrm{SO}_{2}$ was oxidized to $\mathrm{SO}_{4}{ }^{2-}$ with a $\mathrm{H}_{2} \mathrm{O}_{2}$ solution and determined by ion chromatography. Samplers were set up in 13 locations at Mt. Hiei and also at an air-pollution monitoring station of Kyoto city. The relative standard deviation for $\mathrm{NO}_{2}$ and $\mathrm{SO}_{2}$ determinations by these gas samplers were $1.5 \sim 4.0 \%$ and $3 \sim 10 \%$, respectively. The average concentration of atmospheric $\mathrm{NO}_{2}$ at $\mathrm{Mt}$. Hiei was about $7 \mathrm{ppb}$. The $\mathrm{NO}_{2}$ concentration and its distribution along the slope of Mt. Hiei changed considerably both daily and seasonally. However, the concentration of atmospheric $\mathrm{SO}_{2}$ at $\mathrm{Mt}$. Hiei, with a mean value of about $3 \mathrm{ppb}$, was lower than that of $\mathrm{NO}_{2}$, and scarcely changed.
\end{abstract}

Keywords : passive sampler; $\mathrm{NO}_{2} ; \mathrm{SO}_{2}$; ambient air of mountains; Mt. Hiei.

$$
1 \text { 緒言 }
$$

世界的に酸性雨なざ酸性降下物による森林衰退が報告 されており，京都においても比㸚山及びその周辺の山 で, 近年, マツやスギの立ち枯れが顕著である. そこで 著者らは京都里山での土㙵酸性化に関する研究を行い, 京都盆地を囲む比㕡山など主な 15 の山々で土壌の酸性

* 京都工芸繊維大学工芸学部物質工学科,

** 京都工芸繊維大学環境科学センタ一,

*** 京都工芸繊維大学繊維学部高分子学科: 606 京都市 左京区松ヶ崎御所海道町
度と化学組成を調べ, 土㙵 $\mathrm{pH}$ の平均值が 4.26 とかな り酸性であり, 特に京都盆地を三方から井んでいる山の 土壌緩衝能の低下が推測された ${ }^{1)}$. 更にこれらの山の土 㙵特性は標高により異なることも明らかとなった 2 .

本研究では, 京都盆地の山の土㙵酸性化の原因を解明 する研究の一環として, 山間部における酸性大気污染物 質 $\left\{\right.$ 二酸化窒素 $\left(\mathrm{NO}_{2}\right)$, 二酸化硫黄 $\left.\left(\mathrm{SO}_{2}\right)\right\}$ の簡易測 定法について検討した。 山間部における酸性大気污染物 質の測定は, 苗村ら ${ }^{3) 4}$ の研究を除いてはほとんど行わ れていない，通常の自動測定器では設置のための費用や 場所, 電源の問題などから任意の場所での広域的な測定 
は困難である。そこで多地点における同時測定が可能で 小型, 軽量で電源なよ゙が必要ないため任意の場所に設置 でき, 又安価で取り扱いが容易なパッシブサンプラーを 用い, 山間部における $\mathrm{NO}_{2}$ 及び $\mathrm{SO}_{2}$ の分析法を検討 し, 比颚山におけるこれら微量大気污染物質濃度の測定 に適用した。

\section{2 実験方法}

\section{$2 \cdot 1$ 大気環境中の $\mathrm{NO}_{2}$ の測定法}

$\mathrm{NO}_{2}$ 測定用パッシブサンプラーは, 生活環境中の $\mathrm{NO}_{2}$ が人間の健康へ与える影響を調べるため, 個人被 ばく量測定用に考案された柳沢式のフィルターバッチを 用いた ${ }^{5)}$.このパッシブサンプラーは, 吸収沪紙として セルロース繊維製沃紙にトリエタノールアミンを含浸さ せ，その上にはっ水性のポリフロンフィルター（四フッ 化エチレン樹脂製）を 5 枚重ねバッジケースに入れた ものである. 大きさが $5 \mathrm{~cm} \times 4 \mathrm{~cm} \times 1 \mathrm{~cm}$, 重量 $16 \mathrm{~g}$ と 小型, 軽量で電源等もないため任意の場所に取り付ける ことができる.

柳沢式フィルターバッジを設置し，24 時間暴露後回 収し，バッジケースから吸収沪紙を取り出しふた付き試 験管に入れ, ザルツマン試薬 $10 \mathrm{ml}$ を加え, ふたをし

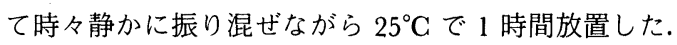
発色は 30 分以上でほぼ一定となるだ, 本法では発色 時間を 1 時間とした. 発色が完了した液を $10 \mathrm{~mm}$ の石 英セルを用い, 波長 $545 \mathrm{~nm}$ で吸光度を測定した.ザル ツマン試薬は, スルファニル酸 $5 \mathrm{~g}$ を約 $700 \mathrm{ml}$ の蒸留 水に溶解した後, $50 \mathrm{ml}$ のリン酸 $(85 \%)$ を加えてよく 混合した後, $0.1 \mathrm{wt} \%$ の-(1-ナフチル)エチレンジア ミン二塩酸塩溶液 $50 \mathrm{ml}$ を添加し, 蒸留水を加えて 11 とした混合溶液である．亜硝酸イオンの標準液は，1000 ppm の和光純薬製イオンクロマトグラフ用標準液を用 いた. 分光光度計は, 日本分光製 Ubest-30を使用し た. 大気中の $\mathrm{NO}_{2}$ 濃度は, ザルツマン法による試料吸 光度から算出式に従って日平均濃度を求めた。

物質拡散の式などから, $\mathrm{NO}_{2}$ の吸収量 $\mathrm{M}[\mathrm{mol}]$ は, 式(1)で表すことができる5).

$$
\mathrm{M}=K_{\mathrm{OG}} A \tau(1 / R T) f_{\mathrm{NO}_{2}} \times 10^{-9}
$$

$K_{\mathrm{OG}}$ : 総括物質移動係数, $A$ : 界面面積 $\left[\mathrm{cm}^{2}\right]$,

$\tau$ : 暴露時間 $[\mathrm{s}], f: \mathrm{NO}_{2}$ 濃度 $[\mathrm{ppb}]$

$20^{\circ} \mathrm{C}$ での $\mathrm{NO}_{2}$ の吸収量は, 最も平均的な風速 2.0 $\mathrm{m} / \mathrm{s}$, 湿度 $60 \%$ での $K_{\mathrm{OG}}=0.14 \mathrm{~cm} / \mathrm{s}$ を用いて式 $(2)$ となる。

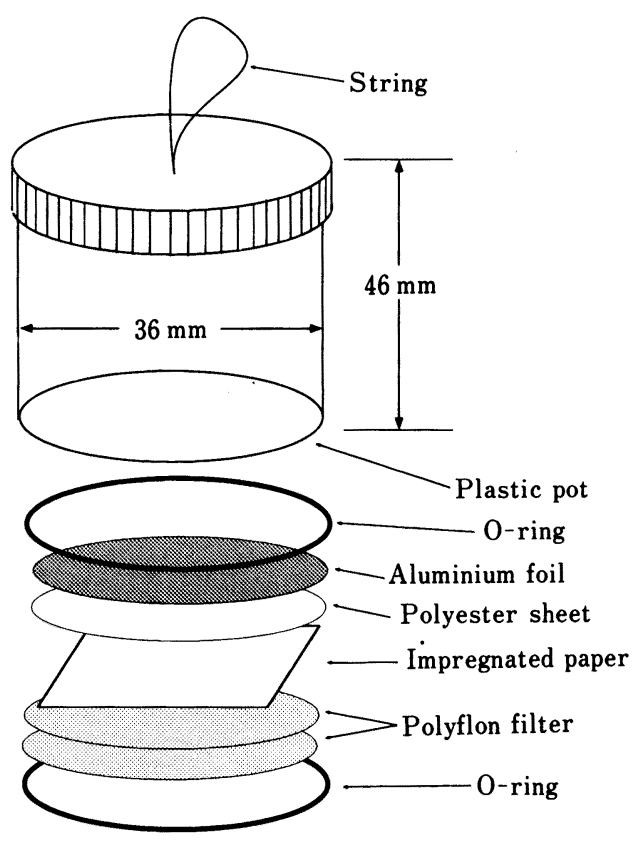

Fig. 1 Exploded diagram of the passive sampler for $\mathrm{SO}_{2}$

$$
\mathrm{M}=4.97 \times 10^{-9} f_{\mathrm{NO}_{2}}
$$

ザルツマン法による亜硝酸イオンの検量線と試料の吸 光度から日平均濃度 $f_{\mathrm{NO}_{2}}$ を求める.

\section{$2 \cdot 2$ 大気環境中の $\mathrm{SO}_{2}$ の測定法}

$\mathrm{SO}_{2}$ 測定用パッシブサンプラーは, 北海道大学で検 討されている分子拡散サンプラー ${ }^{6) 7)}$ を参考にして自作 した (Fig. 1). 高さ $46 \mathrm{~mm}$, 直径 $36 \mathrm{~mm}$ のポリカーボ ネート製の容器の底をくり抜き, 直射日光を遮へいする ために市販のアルミはくを，吸収沃紙への染み込み防止 のためにポリエステルフィルムを敷き，試薬含浸洰紙を 挟み, その下にポリフロンフィルターを 2 枚重水, そ れらを 2 個の $\mathrm{O}$ リングで上下から挟み，しっかり固定 した.アルミはく，ポリエステルフィルム及びポリフロ ンフィルターは直径 $36 \mathrm{~mm}$ に切り抜いた。 試薬含浸沪

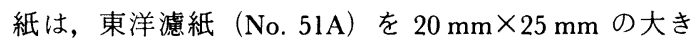
さに切り, 約 $60^{\circ} \mathrm{C}$ の蒸留水に 30 分間, 2 回ずつ浸し て洗浄を行い，2.5\% 炭酸ナトリウム水溶液に約 1 時間 浸し，それをデシケーター中で自然乾燥させたものを用 いた. ポリエステルフィルムは, OHP 用フィルム（厚 さ $100 \mu)$ を，ポリフロンフィルターは，東洋濾紙製

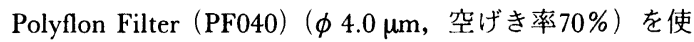


用した.このポリフロンフィルターは, エアロゾルを除 去する目的のほかに，風速の大小によるガス吸収量の相 違を打ち消し，ガス成分の吸收を，ポリフロンフィル 夕一内の細孔を通じ分子拡散のみにより進行させるため のものである. 又, はっ水性であり, 雨水の侵入を防ぐ ことができる，パッシブサンプラーは作製後, 使用直前 まで二重にしたビニール袋に収納し，作製後できるだけ 早く使用するようにした.

自作した $\mathrm{SO}_{2}$ 測定用パッシブサンプラーを目的場所 に設置し，一定時間（15３0 日間）暴露後回収した. 吸收沪紙を $30 \mathrm{ml}$ の広山のポリ容器に入れ, 蒸留水 15 $\mathrm{ml}$ を加え亜硫酸イオンにし, その直後に $30 \%$ 過酸化 水素水 $0.3 \mathrm{ml}$ を添加して酸化して硫酸イオンにした. この試料は冷蔵庫に保存すると少なくとも 2 週間は安 定である．陽イオン交換カートリッジ（東ソ一製 Toyopak IC-SP S）を装着した $2 \mathrm{ml}$ 注射器でイオンクロマト グラフ装置に試料 $500 \mu \mathrm{l}$ を注入した. イオンクロマト グラフ装置は, 島津製 LC-10A 型を使用した。 カラム は，ガードカラム Shim Pack IC-GA3 を前に接続した Shim Pack IC-A3 を用い, カラムオーブンは $40^{\circ} \mathrm{C}$ 一定 とした。溶離液は $3.2 \mathrm{mM}$ ビストリス $-8 \mathrm{mM}$ p-ヒドロ キシ安息香酸を使用した。

\section{$2 \cdot 3$ 比数山における $\mathrm{NO}_{2}$ 及び $\mathrm{SO}_{2}$ の測定法}

ケーブル比㕡駅付近の標高 $700 \mathrm{~m}$ の地点から, きら ら坂の麓付近（標高 $170 \mathrm{~m}$ ）まで高度約 30 $80 \mathrm{~m}$ の間 隔で 13 か所のサンプリング地点を設定した（Fig. 2). 標高は, いすぐ製作所製の高度計を用いて決定した. 比 較的風通しがよい場所にある木の高さ $1.5 \sim 2.0 \mathrm{~m}$ の所 を選び，アルミパック（窒素雾囲気にて密封）よりフィ ルターバッジを取り出し, 直ちに測定場所に設置した. このバッジは裏側から雨が入ることが分かったので, 雨 の降る可能性のある場合はビニールで裹側を覆った. 24 時間の暴露後, チャック付きビニール袋に入れ, 更にア ルミパックに入れて密封して研究室に持ち䚻った. 直ち に $\mathrm{NO}_{2}$ を吸収した沃紙を取り出してザルツマン法によ り分析を行い, $\mathrm{NO}_{2}$ 濃度の算出式に従って日平均濃度 を求めた. $\mathrm{SO}_{2}$ 測定用パッシブサンプラーも密封した ビニール袋から取り出し, 直ちに測定場所に設置した. サンプラーは，たこ系をつけて風などで摇れ動かないよ うガムテープ等でしっかりと下向きに設置した．20日 間（あるいは15 日間）の暴露後, チャック付きビニー ル袋に入れ密封して研究室に持ち帰り, 吸収沪紙から $\mathrm{SO}_{2}$ を抽出した溶液は冷蔵庫に保存し, 1 週間以内に分 析を行った。このパッシブサンプラーを京都市の大気污

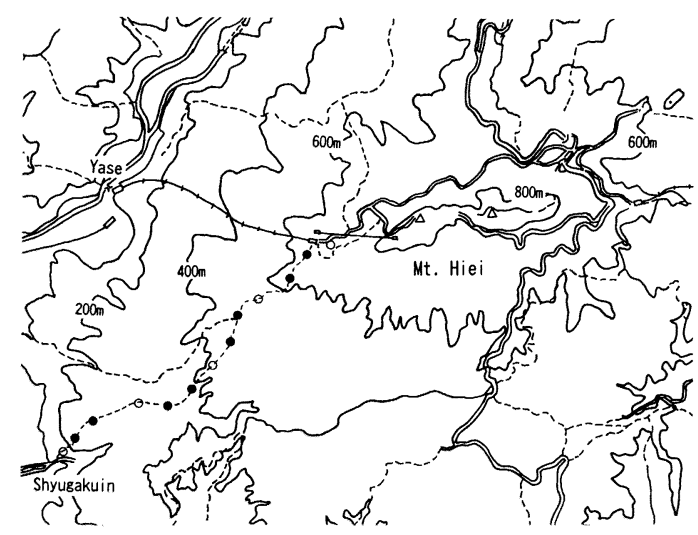

Fig. 2 Sampling location in Mt. Hiei $\mathrm{O}$ : sampling points for $\mathrm{NO}_{2}$ and $\mathrm{SO}_{2} ; \mathrm{O}$ : sampling points for $\mathrm{NO}_{2}$ only

染測定局にも設置し, 溶液導電率法により測定された測 定局の值とパッシブサンプラーの值を比較し，検量線を 作成した。これを用い, 比㪍山で得られた吸収量を環境 濃度に換算し, 日平均濃度を求めた。

\section{3 結果と考察}

\section{$3 \cdot 1 \quad \mathrm{NO}_{2}$ 測定用パッシブサンプラーの性能評価}

ガスの拡散を利用した短期暴露用の $\mathrm{NO}_{2}$ のパーソナ ルサンプラーとしては, 本法で用いた柳沢ら ${ }^{5)}$ 方法の ほかに, 福井 ${ }^{8)}$, 天谷 ${ }^{9)}, \mathrm{Ferm}^{10)}$ 及び平野 ${ }^{11)}$ の方法が 報告されている.ここでは環境中の低濃度の $\mathrm{NO}_{2}$ を精 度よく簡便に測定できるサンプラーとして, 柳沢と天谷 のサンプラーの両方について沪紙の空試験値, 測定の感 度及び同地点に設置したときの個々のサンプラーの吸収 量のばらつき等について調べた.

柳沢式サンプラーの空試験の平均值（ザルツマン法の 吸光度）は 0.016 であり, 環境大気濃度に換算して $0.90 \mathrm{ppb}$ であった。平地において穏和な気候条件下で このサンプラーごとのばらつきを調べると， $0.2 \%$ $(n=5)$ と非常に小さかった. 次に比餐山において, 1 か所に 5 個ずつサンプラーを設置してばらつきを調べ たところ, 日なたと日陰で相対標準偏差が $4.0 \%$ とやや 高かったほかは, 風向きの影響もほとんどなく $1.5 \%$ と ばらつきは小さかった。柳沢式の標準偏差は, 環境大気

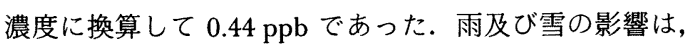
かなりの豪雨のとき以外はほとんどなかった，又，トリ エタノールアミン水溶液を沪紙に含浸させ, 乾燥させた $\mathrm{NO}_{2}$ 測定用分子拡散サンプラーは, 気温低下に伴い 


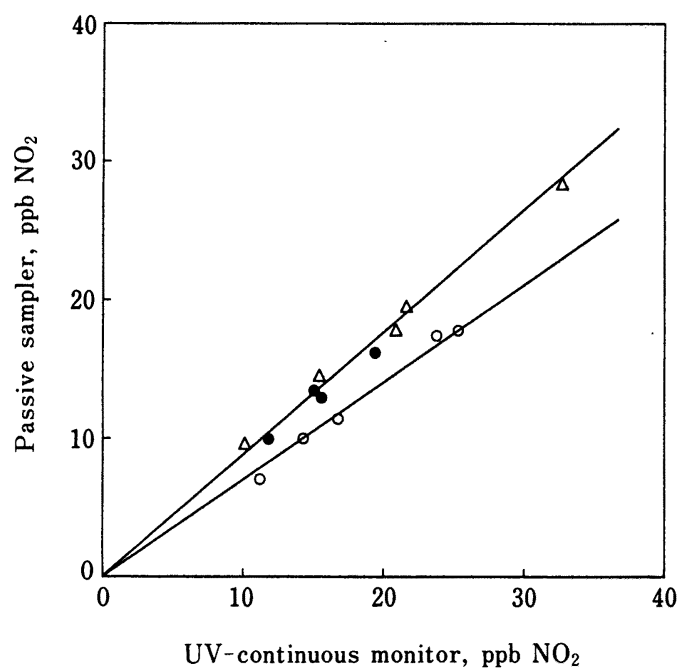

Fig. 3 Comparison of passive samplers to a standard continuous monitor

$\bigcirc$ : February; : March; $\triangle$ : April

$\mathrm{NO}_{2}$ 捕集効率が急激に低下することが指摘されてい る ${ }^{6)}$. 山間部では冬季と夏季ではかなりの温度差があ り，例えば比㕡山では 1995 年に $-10^{\circ} \mathrm{C}$ (2 月) $~ 32^{\circ} \mathrm{C}$ （8月）と約 $40^{\circ} \mathrm{C}$ の温度差があった。そこで比㚲山か ら約 $10 \mathrm{~km}$ 南西方向にある京都市左京区の大気污染測 定局 (高野) に1996 年 2 月から4 月にかけて柳沢式サ ンプラーを設置し自動測定值との比較を行い，その結果 を Fig. 3 に示す. 2 月の気温は $-2.0 \sim 1.0^{\circ} \mathrm{C}, 3$ 月及び 4 月の平均気温はそれぞれ $5^{\circ} \mathrm{C}, 15^{\circ} \mathrm{C}$ であった。 3 月, 4 月では, 柳沢式サンプラーによる值は自動測定值と比 較するとやや低值であったが，良い相関関係を示した $\{y=0.860 x+0.247(r=0.996)\}$. 一方, 2 月の值はこれ らの值之比較すると低く，気温が $0^{\circ} \mathrm{C}$ 付近より低くな ると $\mathrm{NO}_{2}$ 捕集効率の低下が認められたが，相関関係は 良かった $\{y=0.723 x-0.404(r=0.998)\} .-5.0^{\circ} \mathrm{C}$ 以下 の冬季の比阽山に設置してもサンプラーの吸収効率は大 きくは低下せず，気温 $0^{\circ} \mathrm{C}$ 前後で $\mathrm{NO}_{2}$ 捕集効率の低下 がやや見られるがその温度付近では一定であり，十分補 正できることが分かった.

一方，天谷式を比㕡山，大文字山など山間部に設置し た場合は相対標準偏差が $10 \%$ 以上と大きく，吸収速度 が風速によって変化することが指摘されているよう に5)，風などの影響をかなり受けることが分かった。こ れは山間地のような低濃度地域 (7 ppb 以下) について は天谷式は適当ではないという苗村ら ${ }^{4)}$ の結果とも一致

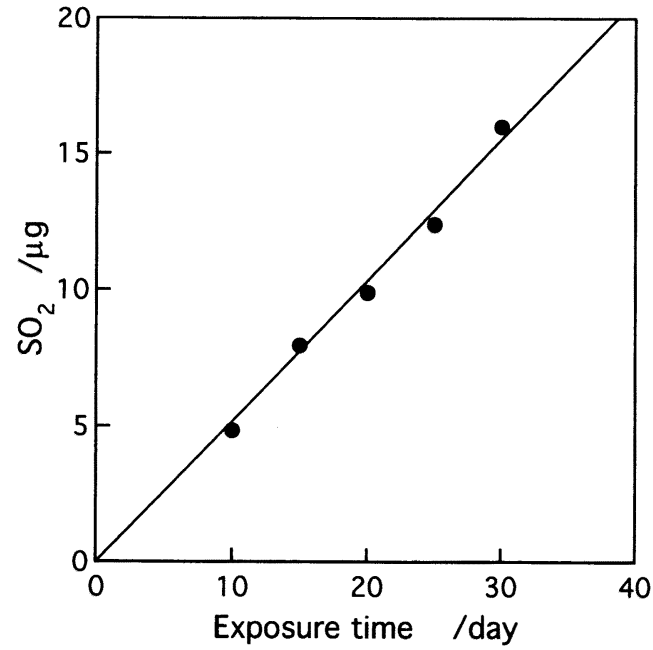

Fig. 4 Relationship between the accumulated values of $\mathrm{SO}_{2}$ concentration and the exposure time

した，そこで本研究では，雨や風の影響をほとんど受け ず，個々のサンプラーの吸収量のばらつきも少ない柳沢 式のサンプラーを，比呫山など環境中の $\mathrm{NO}_{2}$ 測定に用 いることとした.

\section{$3 \cdot 2 \mathrm{SO}_{2}$ 測定法の検討}

自作した $\mathrm{SO}_{2}$ 測定用パッシブサンプラーの吸収沪紙 の空試験值, 暴露時間を変化させたときの吸収感度, 吸 収量のばらつき等について調べた。吸収洰紙の空試験値 は, 硫酸イオン濃度で 10 回の平均值が $0.16 \mathrm{ppm}$ であ った．又，濃度が時間的に変化する大気環境中で測定を 行い正しい日平均濃度を得るためには，吸収感度が時間 とともに変わらないことが必要である．そこで京都市左 京区の大気測定局にこの $\mathrm{SO}_{2}$ 測定用パッシブサンプ ラーを設置し，10，15，20，25，30 日暴露後の $\mathrm{SO}_{2}$ 吸 収量を測定した。この結果を Fig. 4 に示す.測定期間 中 $\mathrm{SO}_{2}$ の日平均値はほとんど変化なく $3.6 \mathrm{ppb}$ 付近で あり, $\mathrm{SO}_{2}$ 吸収量は暴露時間とともに直線的に増加し, 相関係数は 0.99 以上であった。 よって 30 日間の暴露 期間中, 吸収感度は変化せず, 総括物質移動係数は一定 であり，大気環境中の $\mathrm{SO}_{2}$ 測定として問題ないことが 明らかとなった。平地において 30 日間暴露したときの このサンプラーの捕集誤差は $5.2 \%(n=5)$ であった. 次に比㻏山の異なる標高にそれぞれ 5 個ずつ設置して 同様に吸収量のばらつきを調べたところ，相対標準偏差 3〜10\%と場所によってばらつきにやや違いがあったも 
報 文 山田, 吉田, 胡, 山田: パッシブサンプラーを用いる山間部における大気中 $\mathrm{NO}_{2}, \mathrm{SO}_{2}$ 簡易測定法

Table 1 Analytical results of $\mathrm{NO}_{2}$ at $\mathrm{Mt}$. Hiei and at continuous monitoring station of Sakyo-ku in Kyoto city

\begin{tabular}{|c|c|c|c|c|c|c|}
\hline \multirow{2}{*}{ Time } & \multicolumn{3}{|c|}{ Mt. Hiei, ppb $\mathrm{NO}_{2}$} & \multicolumn{3}{|c|}{ Sakyo-ku, ppb $\mathrm{NO}_{2}$} \\
\hline & Altitude $700 \mathrm{~m}$ & Altitude $210 \mathrm{~m}$ & Average & Maximum & a.m. 5:00 & Average \\
\hline \multicolumn{7}{|l|}{1995} \\
\hline $5 / 9-10$ & 9.5 & $16.1^{\dagger}$ & 13.5 & 66 & 14 & 34.0 \\
\hline $7 / 27-28$ & 9.0 & 11.7 & 9.9 & 46 & 12 & 19.4 \\
\hline $8 / 28-29$ & 2.1 & 3.3 & 2.5 & 18 & 7 & 9.7 \\
\hline $9 / 13-14$ & 7.1 & 8.1 & 7.3 & 41 & 12 & 20.5 \\
\hline $10 / 12-13$ & 4.1 & 11.1 & 7.8 & 57 & 12 & 23.0 \\
\hline $10 / 13-14$ & 1.9 & 3.5 & 2.8 & 30 & 7 & 16.3 \\
\hline $10 / 18-19$ & 4.3 & 6.4 & 5.6 & 36 & 6 & 17.0 \\
\hline $10 / 19-20$ & 1.1 & 1.4 & 1.1 & 27 & 11 & 9.3 \\
\hline $10 / 26-27$ & 1.5 & 2.8 & 2.2 & 50 & 8 & 16.5 \\
\hline $10 / 30-31$ & 20.8 & $20.2^{\dagger}$ & 20.6 & 53 & 23 & 30.8 \\
\hline $11 / 15-16$ & 3.0 & 8.2 & 5.4 & 45 & 5 & 20.0 \\
\hline $12 / 22-23$ & 18.0 & 21.8 & 19.7 & 58 & 29 & 32.9 \\
\hline \multicolumn{7}{|l|}{1996} \\
\hline $1 / 9-10$ & 3.4 & 6.7 & 4.9 & 43 & 4 & 15.0 \\
\hline $1 / 24-25$ & 4.3 & 8.0 & 5.9 & 49 & 14 & 19.5 \\
\hline $1 / 29-30$ & 2.2 & 4.7 & 3.1 & 32 & 20 & 17.8 \\
\hline $2 / 26-27$ & 1.2 & 2.7 & 1.7 & 61 & 6 & 26.3 \\
\hline
\end{tabular}

$\dagger$ altitude $170 \mathrm{~m}$

のの満足のいく結果を得た.

沪紙に捕集した $\mathrm{SO}_{2}$ は, 過酸化水素水を含む水溶液 で酸化し硫酸イオンにした後イオンクロマトグラフ法で 測定したが, 直接注入すると硫酸イオンのピークの前に 負のピークが生じるため正確な測定ができなかった。こ れは吸収剂として用いた炭酸ナトリウムの影響であり， 陽イオン交換カートリッジを装着してナトリウムイオン を除去後イオンクロマトグラフ装置に注入したところ， 負のピークは生じず, 精確に硫酸イオン濃度が測定でき ることが分かった. 又, 山間部の大気中の $\mathrm{SO}_{2}$ はかな り低濃度であるが, 注入量を $500 \mu \mathrm{l}$ に増やすと, 硫酸 イオン濃度で $0.1 \mathrm{ppm}$ まで定量可能であり, 暴露時間 15 日以上で比㕡山などの山間部における大気中の $\mathrm{SO}_{2}$ を測定するのに十分な感度が得られた。

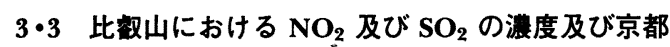
市大気測定局の值との比較

柳沢式サンプラーを用いて, 1995 年 5 月より比㩚山 のサンプリング地点 13 か所において 24 時間暴露で測 定を開始した。1995 年 5 月から 1996 年 2 月までの比 㪍山における $\mathrm{NO}_{2}$ 濃度の結果を Table 1 に示す. 比㕡 山の $\mathrm{NO}_{2}$ 濃度の平均值は 7.1 と $10 \mathrm{ppb}$ 以下で, 左京 区大気污染測定局の平均值 $20.5 \mathrm{ppb}$ と比較すると約 3 分の 1 の值であった. 又, 比㚲山の $\mathrm{NO}_{2}$ 濃度範囲は
1.1 20.6 ppb と, 高濃度のときは低濃度の約 20 倍で, 左京区大気污染測定局の 9.3 $34.0 \mathrm{ppb}$ と比較すると濃 度範囲が広く, 時間変化が大きいことが分かった，又, $\mathrm{NO}_{2}$ 濃度が $20 \mathrm{ppb}$ 前後と非常に高かった日は, 1995 年 5 月から 1996 年 2 月にかけて 16 回測定した中で 10 月 30〜31 日と 12 月 22 23 日の 2 回観察された.こ れらの日は京都市左京区の大気污染局の值も平均 30.8 , $32.9 \mathrm{ppb}$ と他の日と比較するとかなり高く, 午前 5 時 になってもそれぞれ $23,29 \mathrm{ppb}$ と濃度が下がらず気温 の逆転層の形成が考えられた。これらの日, 天気は量り で日照時間は少なく, 比㕡山測定局での風向が西南 西〜南南西の範囲であった，又，自作した $\mathrm{SO}_{2}$ 測定用 パッシブサンプラーを用いて，1995 年 11 月より比龼山 の $\mathrm{NO}_{2}$ のサンプリング地点 13 か所のうち, 5 か所 (1996 年 2 月 27〜3 月 13 日は 7 か所) において 20 日 あるいは15 日暴露で計 4 回測定を行った結果を Table 2 に示す. 比㕡山の $\mathrm{SO}_{2}$ の日平均濃度は $3.1 \sim 3.6 \mathrm{ppb}$ の範囲でその間の平均值は $3.3 \mathrm{ppb}$ であり, 約 $10 \mathrm{~km}$ 南西の左京区大気污染測定局における $\mathrm{SO}_{2}$ 濃度の平均 值 $3.7 \mathrm{ppb}$ と比較するとやや低い值であった. 藤田は, 日本の $\mathrm{SO}_{2}$ の幾何平均濃度は寒候期で $5.6 \mathrm{ppb}$ だが, 測定局の多くは市街地に置かれているため過大に見積も っている可能性があり, 土地利用の状況も考慮して日本 全域での $\mathrm{SO}_{2}$ の平均濃度は $3.2 \mathrm{ppb}$ と推定している ${ }^{12)}$. 
Table 2 Analytical results of $\mathrm{SO}_{2}$ by passive sampler in Mt. Hiei

\begin{tabular}{|c|c|c|c|c|c|}
\hline \multirow{2}{*}{ St. No. } & \multirow{2}{*}{ Altitude $/ \mathrm{m}$} & \multicolumn{4}{|c|}{ Diurnal average of $\mathrm{SO}_{2}, \mathrm{ppb}$} \\
\hline & & $11 / 25 \sim 12 / 15$ & $1 / 9 \sim 1 / 29$ & $1 / 30 \sim 2 / 14$ & $2 / 27 \sim 3 / 13$ \\
\hline 1 & 700 & - & 3.1 & 3.8 & 3.3 \\
\hline 4 & 560 & 3.7 & 3.3 & 3.8 & 3.3 \\
\hline 6 & 470 & - & - & - & 3.0 \\
\hline 7 & 440 & 3.8 & 3.1 & 3.6 & 3.2 \\
\hline 10 & 320 & 3.7 & 3.1 & 3.7 & 3.1 \\
\hline 11 & 270 & - & - & - & 3.2 \\
\hline 13 & 170 & 3.0 & 2.9 & 3.0 & 2.9 \\
\hline \multicolumn{2}{|c|}{ Mean value } & 3.5 & 3.1 & 3.6 & 3.1 \\
\hline \multicolumn{2}{|c|}{$\begin{array}{l}\text { Continuous monitoring } \\
\text { data at Sakyo-ku station }\end{array}$} & 3.4 & 3.4 & 4.2 & 3.7 \\
\hline
\end{tabular}

比瑴山の寒候期の值は，この推定値とほぼ一致する結果 となった。

本研究で検討した $\mathrm{NO}_{2}$ 及び $\mathrm{SO}_{2}$ 測定用パッシブサ ンプラーを用いると, 山間部における低濃度 $\mathrm{NO}_{2}$ 及び $\mathrm{SO}_{2}$ 測定が可能であることが分かった。しかし，比㕡 山のような山間部での $\mathrm{NO}_{2}$ 濃度は日変化が大きく, 短 期暴露測定（24 時間暴露）のほかに長時間暴露測定を 併用して行う必要があり, 長時間暴露測定についても検 討を行っている. 又, 大気中の $\mathrm{SO}_{2}$ 濃度はかなり希薄 であり, サンプラーの空試験值の低減化や測定の高感度 化を更に検討する必要がある.

最後に, 大気測定局のデー夕を提供くださった京都市役 所衛生局環境保全室公害規制課, 又左京大気測定局での測 定にご協力いただいた京都市衛生公害研究所並びに京都市 聴覚言語障害者センターに感謝の意を表する.

\section{文}

1）山田 武, 大野原 基, 佐藤昌憲, 山田 悦: 環 境科学会誌, 9,211（1996）.
2）山田 武, 大野原 基, 山田 悦: 環境科学会 1995 年会講演要旨集, p. 59 (1995).

3）苗村晶彦, 川口優子, 中根周歩, 福岡義隆, 佐久 川弘, 土谷彰男: 環境科学会 1995 年会講演要 旨集, p. 63 (1995).

4) 苗村晶彦, 中根周歩: 環境科学会誌, 9, 65 (1996).

5）柳沢幸雄, 西村 肇: 大気污染学会誌, 15, 316 (1980).

6）森川多津子, 太田幸雄，村尾直人，溝口 勲：環 境科学会誌, 3, 223 (1990).

7）前田高尚, 太田幸雄, 村尾直人, 溝口 勲, 小林 弘幸：環境科学会誌, 7, 129 (1994).

8）福井昭三: 分析化学 (Bunseki Kagaku), 12, 1005 (1963).

9）天谷和夫：大気污染研究, 9, 192 (1974).

10) M. Ferm: A sensitive diffusional sampler, Swedish Environmental Research Institute L91-172, p. 1 (1991).

11）平野耕一郎：文部省科学研究費補助金・国際学術 研究（伊永班）研究成果報告書, Vol. 1, p. 37 (1996).

12）藤田慎一：環境科学会誌, 9, 185 (1996).

\section{要旨}

京都盆地の山の土壌酸性化の原因を解明する研究の一環として，電源などが必要ないため任意の場所 に設置でき多地点における同時測定が可能なパッシブサンプラーを用い，山間部における二酸化窒素 $\left(\mathrm{NO}_{2}\right)$ 及び二酸化硫黄 $\left(\mathrm{SO}_{2}\right)$ の分析法を検討し, 比㪍山におけるこれら微量大気污染物質濃度の測 定に適用した. $\mathrm{NO}_{2}$ 測定には柳沢式パッシブサンプラーを用い， 24 時間暴露後ザルツマン法で測定し た. $\mathrm{SO}_{2}$ 測定には炭酸ナトリウム含浸フィルターを保持したサンプラーを自作し，20日間暴露後過酸 化水素水で酸化して硫酸イオンとし，イオンクロマトグラフ法で測定した。サンプラーは比㪍山の 13 か所と京都市大気測定局に設置した。山間部での $\mathrm{NO}_{2}$ 及び $\mathrm{SO}_{2}$ 測定の相対標準偏差はそれぞれ 1.5 4.0\% 及び 3 10\% であった．比㕡山の $\mathrm{NO}_{2}$ 濃度の平均值は約 $7 \mathrm{ppb}$ で， $\mathrm{NO}_{2}$ 濃度及びその標 高分布は日変化並びに季節変化が大であった. $\mathrm{SO}_{2}$ 濃度の平均值は約 $3 \mathrm{ppb}$ で $\mathrm{NO}_{2}$ 濃度より低く, 濃 度変化も小さかった. 